\title{
"So agreeable and suitable a place": the character, use and provisioning of a late eighteenth-century suburban villa
}

\section{Introduction}

In March 1791, the Hon. Mary Leigh wrote to her lawyer and friend Joseph Hill about her Kensington home: 'my wish would be to continue it exactly the same it now is, any alteration would much lessen it in my estimation ... it is impossible for me to have so agreeable and suitable a place as is the Grove House in every particular'. ${ }^{1}$ In many ways, this description encapsulates the attraction of the suburban villa for a growing number of elite families in late eighteenth-century London: a place that was convenient for, yet removed from the city. But what was the balance between these two motivations? Should we see the burgeoning 'villadom'2 as convenient for London - a place for commuters to the commercial and social life of town? Or should we see it as a retreat from this hurly-burly - a place of 'polite retirement'? ${ }^{3}$ In short, what was the suburban villa for?

Traditionally, the villa was a private rural retreat for the urban elite, set in a country estate away from the city and with unwanted visitors excluded to create a particular social milieu. Pliny had his Tuscan villa where he could escape public ceremony and the merchant princes of Renaissance Italy did the same - a practice formulated by Palladio. ${ }^{4}$ This practice was picked up by the burghers of the Dutch Republic during the golden age, and by the French and English aristocracy who built villas and palaces in the environs of their respective capitals. ${ }^{5}$ Here, they rubbed shoulders with a growing number of prosperous merchants and professionals, the result being a mix of houses, from grand and famous mansions to more modest and obscure dwellings. ${ }^{6}$ The former included Lord Burlington's Chiswick House, visited (and criticised) as the ideal Palladian villa; Pope's Twickenham villa, the subject of over 30 published views by 1811; Marble Hill, built for the Countess of Suffolk and also favoured as a subject for painting; the Earl of Mansfield's seat at Kenwood, which was increasingly visited on excursions from 
London, and Walpole's Strawberry Hill, another magnet for visitors. ${ }^{7}$ The fame of these places undermined their seclusion, seen by many contemporary commentators as a key part of the attraction of the suburban villa. As Roger North stated around 1690: 'A villa, is quasy a lodge, for the sake of a garden, to retire to injoy and sleep, without pretence of enterteinement of many persons'.$^{8}$

Riverside settings were favoured, Defoe noting in the early eighteenth century that 'from Richmond to London, the river sides are so full of ... beautiful buildings, charming gardens and rich habitations of gentlemen of quality that nothing in the world can imitate it'. ${ }^{9}$ The river made the setting attractive, but also offered the convenience of water transport. As such places became increasingly populous through the eighteenth century, villas tended to be built instead on higher ground, away from the crowds and in a position to enjoy open views. ${ }^{10}$ Despite this, accessibility remained important, especially for occupants who retained businesses in London. Commuting was noted by Defoe and became ever more common as roads were turnpiked from the 1720 s and short-stage coaches proliferated from the 1730 s. $^{11}$ This drew suburban developments more firmly into London's sphere and underlined the colonisation of suburbs by a metropolitan elite: Hampstead's Upper Flask Tavern was the meeting place of the Kit-Kat Club and Kensington was increasingly popular with well-placed aristocrats, especially after William and Mary's court came to Nottingham House (later Kensington Palace) in 1690.12

The nature of the suburban villa and its relationship with London was thus complex and changing. Gerhold's analysis outlines the shifting geography and ownership of villas and touches on their (seasonal) occupancy in relation to London homes; but it leaves largely untouched both the character of the villa and its use on a day-to-day basis. Such issues can only be addressed fully through detailed analysis of a single villa, in this instance Grove House in Kensington Gore. Situated to the south of Hyde Park, Grove House was built shortly before 1750, probably for the noted surgeon, Sir Caesar Hawkins. Like many villas, it passed various hands, although most of its occupants remained in place for a number of years, rather than renting on an annual basis as was common elsewhere. ${ }^{13}$ From 1765 it was occupied by Anne Pitt, sister of the Earl of Chatham 
and keeper of the Privy Purse to the Princess of Wales (1751-71). On her emigration to Italy in 1774, Grove House was taken by another well-connected individual with strong ties to London: Sir John Elliott, physician to the Prince of Wales. However, from 1786 at the latest it was occupied by someone with a much lower public profile: the Hon. Mary Leigh, sister of Edward, fifth and last Lord Leigh of Stoneleigh Abbey in Warwickshire.

Born in 1736 and orphaned by the age of 13, Mary had lived in London for much of her life, initially with her guardian, Elizabeth Verney, and later in her own rented house, probably in the vicinity of Hanover Square. We know little about this property, which was probably rented furnished as the small number of bills for furniture during this period record the purchase of the single chairs or tea tables and repairs to curtains. ${ }^{14}$ From 1774 she was jointly responsible for managing the Stoneleigh estates after Edward was declared a lunatic, and appears to have divided her time between London and Stoneleigh Abbey until Edward's death in 1786. At this point, and already 50 years old, Mary inherited a life interest in the Stoneleigh estates, then worth over $£ 13,000$ per annum.15 With considerable wealth at her disposal, she chose to move to Grove House, renting the property from Charles Magnolly at a cost of $£ 400$ per annum. ${ }^{16} \mathrm{Her}$ motivations for moving out of town are unclear, but she retained the lease for the remainder of her life, dividing her time between Kensington, Stoneleigh and Cheltenham.

It is the twenty year period of Mary's occupancy that forms the focus of this paper. In some respects, her arrangements were unusual: she was middle aged and single, yet extremely wealthy (her rental income placed her well within the highest bracket of Massie's 1756 typology ${ }^{17}$ ) and she had no town house from which her suburban villa could form a retreat. These distinctions clearly shaped her behaviour and her use of Grove House; they also make it a useful case against which to test our understanding of the character and purpose of the suburban villa. Moreover, there is a wealth of archival material available, including a very full set of receipted bills, as well as inventories, day books and some correspondence. These are drawn on to address three related areas. First is the character and material culture of the house. What type of environment was needed in a suburban villa; what made it such an 'agreeable and 
suitable' situation, and how was it maintained in this state? Second is the lifestyle of the suburban resident. How was the house used and viewed by Mary: was it the base for a London social life or a retreat from such engagements? Third is the question of supplying and servicing the house. How was it linked into the local and metropolitan economies, and to what extent was this dependent upon Mary's location at particular times of year? Overall, the aim is to establish a clearer picture of the relationship between a suburban villa, the city and the country house.

\section{The material culture of the suburban villa}

Grove House was an archetypal suburban house, both in its architectural form and history. Originally a plain five-bay structure with a central bay and designed for convenience rather than as a show villa, ${ }^{18}$ it had been substantially altered by the time Mary acquired it. An assortment of additions included an extension to the west with a first-floor veranda and a canted oriel to the east. The result was not pretty, Horace Walpole, in typically acerbic style, complaining that it was 'a vile guinguette, that has nothing but verdure, and prospect, and a parcel of wild trees that have never been cut into any shape'. ${ }^{19}$ Anne Pitt improved the interior, commissioning designs from Robert Adam, but also from Walpole himself. She probably adopted the former, and with some success, Mrs Delany writing that 'out of a very ugly odd house ... she has made an uncommon pretty place'. ${ }^{20}$ This is probably the structure that Mary Leigh took on in 1786 . Her lease included stables, two coach houses, gardens and three closes of land, and also the furniture in the house - an arrangement that was by no means unusual. There was undoubtedly much more space at Grove House than would have been available around Hanover Square - an advantage that was, of course, part of the attraction of suburban living.

Although contemporaries agreed that villas were seldom the venue for large-scale entertaining, convention still dictated that the principal rooms and especially the parlour should offer a tasteful setting for polite sociability. Something of this can be gleaned from Repton's portrayal of the 'modern living room' with its informal arrangement of space designed to encourage 
socialising amongst small groups. Women were seen as particularly adept in creating such environments, Vickery highlighting some of the ways in which Jane Austen's heroines engaged in the production of tasteful parlours. ${ }^{21}$ Mary Leigh was quite capable of producing this kind of living space, the Breakfast Room and Dining Parlour at Stoneleigh Abbey being furnished with a range of chairs, small tables, musical instruments and games, many of which she brought into these rooms from elsewhere in the house. ${ }^{22}$ However, the extent to which Grove House also conformed with these ideals is uncertain. The furniture which came with the house was valued at a modest $£ 26410$ s and must have been fairly plain and perhaps quite old. Nonetheless, it appears to have largely served Mary's needs; despite her enormous wealth, she spent modestly and made only limited additions during the course of her twenty years in the house.

Michael Thackthwaite of 7 Marylebone Road, London, presented a consolidated bill for $£ 142$ 17s $61 / 2 \mathrm{~d}$ for furniture supplied between July and December 1786. Although it is unclear whether this furniture was for Stoneleigh Abbey or Grove House, the latter seems the more likely destination..$^{23}$ Either way, the provision was mainly for bedchambers with a long list of bedding and textiles, including two complete beds, incorporating the bedstead, mattress, furniture and matching window curtains, one set trimmed with lace. Alongside these came two dressing tables, glasses and chests of drawers, a basin stand, pot cupboard and close stool, and a small bedside carpet. Items for the principal rooms were few in number: a mahogany bureau, a set of ten mahogany chairs stuffed with curled hair and covered with satin, en suite with two high back chairs, a corner chair, a dumb waiter and three butler's trays. These pieces cannot have had much impact on the overall décor; nor could the small items supplied by Bradshaw and Smith in February and March 1792: a 'square screen mount coverd with green paper \& borderd' and a 'mahog pot cupbaord with oval panelled doors'. ${ }^{24}$ Both of these pieces were described as 'very neat', as was a second screen supplied in May the same year; they spoke of comfort and convenience rather than conspicuous displays of wealth and taste, underlining Mary's apparent satisfaction with domestic respectability. ${ }^{25}$ 
Bradshaw and Smith also charged for fixing the bed and curtains; putting up curtains in the Sitting Room, Dining Room and housekeeper's room; restuffing mattresses; repairing curtains; recovering sofas and chairs, and cleaning two wainscot blinds, 'taking out old canvas \& tacks \& refilling with fine white canvas'.26 The need for regular upkeep and cleaning is also apparent in Thackthwaite's bill. He charged for 'cleaning $30 \mathrm{yds}$ of green tammy' and ' $4 \frac{1}{2} \mathrm{yds}$ of new ditto to make out linings' which came alongside ' 2 very large work muslin window curtains lined with green tammy and fringed'.27 This reminds us of the ongoing cost and work of maintenance, and also the importance of making and keeping a house comfortable and presentable. The textiles used for curtains were practical muslins and cottons, not showy silks and damasks; they were fashionable enough, but were suitable for regular cleaning - something which was becoming increasingly important in genteel households. Smith, Lemire and others have noted that a growing concern with cleanliness was closely linked to notions of respectability and gentility. It was manifest in the nature and washing of clothing and bed linen, but the same was also true of hangings and upholstery. ${ }^{28}$ Once again, Mary's domestic arrangements at Grove House speak of respectability and gentility not luxury and ostentation.

More general upkeep was also necessary. Mary Leigh was apparently a model tenant, commended for the good repair in which she kept the property. Indeed, there was a regular succession of craftsmen coming to the house, especially in the mid 1790 s. ${ }^{29}$ Work was centred on three principal areas. In the main part of the house, there were repairs to the ceiling and new crown glass for the sashes over the stairs; the woodwork in various rooms was painted, most of it in 'plain colour', but some in dead white, fine green and 'grey \& flat'; and repairs made to the chimney board in the dining room. ${ }^{30}$ The principal rooms, then, were in generally good repair. The same could not be said for the service areas, bills recording work on the laundry, scullery, kitchen, still room, pantry, servants hall, housekeeper's room, dairy and coach house, as well as in the stable yard. This included replacing plasterwork, repairing and cleaning windows, repointing brickwork, replacing guttering, digging drains, retiling floors and fitting pipework. ${ }^{31}$ Most extensive was the work undertaken by the carpenter, James Fisher, who also appears to 
have organised other craftsmen working at the house. He was busy repairing skirting, roof timbers, door cases, floor boards and ladders; putting up shelves and candle brackets; taking down and putting up curtains and beds; restringing sash windows, and planing dressers, tables and chopping blocks. A third area in which these craftsmen were kept busy was the garden - an important part of the villa's attraction as a semi-rural retreat. Indeed, Gerhold notes that the owner of a villa in Enfield recorded in her diary that she was 'angry and disappointed at the state of the garden' when she visited in March 1810.32 Mary ensured that her garden did not disappoint in the same way. Fisher was paid for building cucumber frames; repairing gates and fences, including those around the 'Pleasure Ground' and the kitchen garden, and mending the garden seat in the walk. Naylor, meanwhile, charged for painting olive green a range of garden equipment, including frames, roller handles, barrows and tubs.

This everyday expenditure might seem insignificant when compared with the process and cost of fitting out a fashionable London home. However, it is precisely this kind of mundane activity that Williams identifies as being so important in both the economy and management of the country house. ${ }^{33} \mathrm{~A}$ more compact and newer house might have meant smaller bills, but the work still needed to be done if the house was to remain comfortable and 'agreeable' as a place to live. This was true even when the owner was absent, Humphrey Morice's head servant writing to him regularly during his visit to Italy with news of maintenance undertaken at his Chiswick home, also called Grove House, which included painting gates and window frames, and replacing fences swept away by floods. ${ }^{34}$

\section{Life in the suburban villa}

The furnishing of Grove House suggests a place that was intended for comfortable living, rather than large-scale entertaining. Anne Pitt had apparently held balls there every week, linking the house into the social round of London's bon ton. In this, she was in keeping with developments in Hampstead, with its thriving social scene based on an increasingly 'arty, intellectual air'. ${ }^{35}$ 
Large parties were exceptional in suburban villas, however, and were largely reserved for the substantial mansions of famous society or political figures. Both contemporary commentators and Gerhold's survey are clear that villas were places frequented only by family and selected friends. ${ }^{36}$ However, the assumption of both is that the owner would also have a London house in which to receive visitors or entertain at a grander scale. Mary Leigh was not in this position, of course, but still appears to have kept her villa largely private - a retreat from the world. She purchased large amounts of china and silver plate, much of it for Stoneleigh Abbey, but it appears that her purchases from Wedgwood were intended for Grove House. The largest of these, made in 1786 when she was setting up house in Kensington, comprised 235 pieces of 'Green Greek Border' and included plates, terrines, salad and root dishes, cream bowls, muffin plates, pickle saucers, soup terrines and fish drainers. ${ }^{37}$ In addition to these, there was a varied set of cups and saucers for tea, coffee and chocolate; breakfast plates; tea pots, cream pots and slop basins, and a tea chest with caddies. There was also silverware: 6 candlesticks, 4 snuffers, 20 tablespoons, 5 small ladles, 3 cork stoppers, 13 tea spoons, a small fork and 12 coffee spoons. $^{38}$

Together, these would have allowed Mary to entertain in style and at a considerable scale (the order from Wedgwood included 7 dozen concave plates), but this would appear at odds both with the usual purpose of suburban houses and Mary's character: her sociability normally took the form of entertaining small numbers of female friends. However, it is difficult to match these material objects with their usage as we lack direct evidence for the quantity and type of visitor to Grove House. Mary had a wide and well-connected social circle comprising some leading lights in London society - not least the Ladies Sefton, Ormond and Howard. ${ }^{39}$ However, there is little to suggest that they came to see her in Kensington. Indeed, her most frequent visitor was Mrs Hill, the wife of Mary's lawyer, who came over from their house on Queen Street, Lincolns Inn Fields, a distance of about 3.5 miles..$^{40}$ These visits were generally day trips, probably of a similar nature to those described by Lady Lucas who 'went after dinner to Putney, drank tea with Lady Grantham. Return'd to Town'.41 Mary Leigh and Mrs Hill were good friends: they 
exchanged small gifts on a regular basis and Mary frequently enquired after his wife when writing to Joseph Hill about business. There were certainly other visitors, including those seeking her financial assistance. Most notable was a certain Arthur Gregory, apparently a family acquaintance, who asked for $£ 1000$ to purchase for his son a commission in the Dragoons. ${ }^{42}$ Mary refused, citing her receipt of several other requests of a similar nature, but such petitioning reminds us of the importance of the wealthy landowner as patron, even in a suburban setting. For Mary, however, both patronage and visitors defined her life in Warwickshire rather than Kensington. Letters sent from Stoneleigh Abbey make frequent mention of guests just arriving or departing, many of them staying for several days or even weeks. In September 1791, for example, she wrote that she was 'wonderfully engaged in receiving and paying visits' in Warwickshire.43

This presents something of a paradox. The suburban villa was normally a summer retreat from London; yet Mary spent her winters there and her summers in the country. She generally arrived at Grove House in November and stayed until June or early July before spending August and September at Stoneleigh Abbey, and October in Cheltenham. ${ }^{44}$ In effect, Mary was using her villa both as a suburban retreat and a base from which to engage in the London season, even if she did arrive unfashionably early - as Lady Lucas noted, 'the misfortune ever is that in December and January there is no society to be had in Town at all'.45 Kensington was ideally placed for such purposes and was used by Queen Mary as a day retreat from Whitehall in the 1690s. It was around four miles from central London and less than half that to Piccadilly, where at least one of Mary Leigh's friends (Miss Mary Parker) resided. ${ }^{46}$ Such distances could be travelled on foot. Georgian women were both willing and able to walk considerable distances, as Jane Austen's heroines make clear. Elizabeth Bennett is a great walker, although she is criticised in this by the Bingley sisters, who mock both the action and its result in terms of dirty shoes and dresses. Mary's status and age meant that she invariably travelled by coach. Indeed, she had her own carriage and horses, and used these on a regular basis. The day book for Grove House records payments roughly once a week for taking her coach along the turnpike into London, a 
journey that probably took 30-40 minutes at the most. Most often, the destination was given as London, but there were also trips to Temple Bar, the City, the asylum and Mr Hill's. ${ }^{47}$ The exact purpose of all these journeys is uncertain, but they included visits to friends and shops. It is likely that she made more than one visit on each trip, leaving for friends that were not at home one of the 'small gilt visiting cards' recorded as a purchase in the day book. Given the reciprocation expected of polite visiting, this suggests that Mary had social engagements on a minimum of three or four occasions each week. No doubt these visits involved tea, but also playing cards and perhaps a little gambling - the latter suggested by Mary's remark in a letter that 'I have some money in my card purse'.48 Such conservative socialising was typical of many elite women, even in London. Few could aspire to the Beau Monde discussed by Hannah Greig and most were engaged in a far more modest round of reciprocal visiting. As Vickery notes, this could be quite formalised, but often revolved around rituals of tea drinking and polite conversation - much as the visits described by Lady Lucas. ${ }^{49}$

A private coach was, in many ways, the ultimate status symbol, forming a very public display of wealth and status that placed Mary in the upper echelons of London society. In marked contrast to her modest domestic spending, she lavished large sums on her equipage and liveried servants. Her footmen received four sets of clothes apiece - one 'dress livery' trimmed with lace; the others in drab - at a total cost of over $£ 20$ per servant. The coachman got a scarlet laced suit, a drab box coat and two striped waistcoats, whilst the postilion had the same, plus a claret frock suit and an extra two waistcoats. ${ }^{50}$ Such elaborate and brightly coloured clothing was the norm for dress livery. As Styles notes, it linked the servants to particular families and made an impressive show, both on at home and when travelling into town. ${ }^{51}$ The link to family is surely telling in Mary's case: spending on public displays of rank and dignity kept the Leigh name and title in the public eye, despite the formal demise of the barony with her brother's death in 1786. It was this (former) aristocratic title as much as her wealth that gave Mary status; in a formal sense, she may have been simply 'the Honourable Mary Leigh', but brother, father, grandfather and so on had been peers of the realm. 
Despite such public displays of status and her regular socialising, Mary undoubtedly spent a lot of time alone at Grove House. In this, life in the suburban villa was not greatly different from that in the country house. Elite Georgian women spent much of their time drawing, reading, playing music or at needlework. Mary was no bibliophile, noting in a letter that a translation of Homer might be returned directly to Stoneleigh Abbey or 'if you like to read it pray keep it as long as you want it, for I am very sure I shall not read it, it will only be a library book'.52 Despite these protestations, she had over 160 books at Grove House when she died, including a seventeenth-century folio bible, prayer books, sermons and religious texts; 15 volumes of harpsichord music; numerous accounts of travels in Britain and overseas; books on history, science and cookery; and poems, plays and novels. ${ }^{53}$ This was hardly a classic library of the type that formed a necessary adornment to country houses, including Stoneleigh Abbey where her brother had assembled a highly impressive collection during the $1760 \mathrm{~s}^{54}$ These books were not props for elite status, but rather for pleasure; and they were clearly acquired by Mary herself, as most of them dated from the 1790s and 1800s, long after her brother's death. Perhaps most interesting amongst the collection are the travel books and particularly three maps of London, a series of court directories, a pamphlets on the 'Curiosities of Wilton House', and another one entitled 'Description of Cheltenham Spa', Together, these suggest a keen interest in the wider world and her social and spatial setting in the metropolis.

It was the immediate surroundings of suburban villas that made them particularly attractive. Only a few of the grandest houses had extensive parks, places like Roehampton Great House, with its 350 acres, ${ }^{55}$ but all had gardens. The sale catalogue for Gore House - the neighbouring property to Grove House of which Mary acquired the leasehold in 1790 - highlighted the 'spacious elegant villa, with uniform wings', but also the 'kitchen garden, lawn, shrubbery, canal, and rich meadow'.56 The last of these is especially revealing as it suggests grazing for livestock. At Grove House, the day book notes payments for washing and shearing sheep; mowing and haymaking; building and thatching hay ricks; and spreading dung across the fields. ${ }^{57}$ Such activities were not unusual in suburban settings, but for Mary they held an importance that 
went beyond the practicalities of feeding carriage horses. On one occasion, she wrote that 'I was then walking in my garden and thinking how much ground I cou'd spare to make a road into my new field without prejudice to my cows'. On another she noted that 'We have here great appearance of rain \& the glass falls which I observe with much pleasure for my hay rick is finished'.58 These comments suggest a woman thinking more like a landowner than an urban socialite; an impression confirmed in her vigorous defence of her rights in a dispute with her neighbour over a newly erected fence and her ready understanding of the importance of dung.59 They reflect closely the matters that fill the letters written to Morice by his head servant, with their itemisation of the well-being of horses and dogs, problems of trespass, the cost of oats and straw, and decisions about draining fields. ${ }^{60}$ Whilst the land around Grove House was by no means enough to make the villa self-sufficient - an ideal that few rural estates achieved - the concerns expressed in Mary's correspondence are very much in keeping with the tradition of the villa as a rural retreat, set in a productive agricultural world. ${ }^{61}$

\section{Supplying the suburban villa}

The liminal position of the suburban villa was reinforced by the networks of supply that serviced the needs of the house and its owner, locking them into the local and metropolitan economies, but also more distant production systems. Some produce came from the estate at Grove House: there was a gardener and dairy maid on the list of servants, and cows were kept in the fields belonging to the house. ${ }^{62}$ This went beyond a scattering of livestock, introduced to create a feeling of rus en urbe; rather, it was a productive if modest agricultural system - a scaled-down version of the country estate. There is little mention of butter, eggs or vegetables in either the day book or the large collection of surviving bills, suggesting that Grove House (like its larger country cousins) was able to supply many of its own needs in these areas.

Other produce came from local suppliers. The day book records a regular flow of goods, including neat's tongues, pigs, biscuits, corks and vinegar, as well as some seasonal specialities; 
strawberries, for example, were purchased almost every day between mid-June and mid-July. ${ }^{63}$ Whilst the suppliers are not identified here, receipted bills show that Kensington shopkeepers were the main source of meat, fish, poultry, bread, candles and coal for the house. In essence, Mary bought everyday goods locally in much the same way as landowners across the country. She had favoured retailers: John Loader presented bills for fish on 16 occasions; Samuel Kingston sent 14 bills for coal and charcoal; Roger Buckmaster sent 12 bills for meat; William Simpson presented 11 bills for bread; Henry Davis sent 9 for poultry, and James Wheble sent 7 for chandlery. These were generally quarterly accounts and reflected long-standing and regular provisioning of consumables by a set of tradesmen who were central to the functioning of Grove House. ${ }^{64}$ Conversely, Mary's patronage was important within the local economy. The bills record a total expenditure of $£ 121714$ s $5 \mathrm{~d}$ in Kensington shops over the twenty years of her residence - a significant inflow of capital which parallels the more familiar impact of the country house on its neighbouring villages.

Prime consumers were thus key to the prosperity of local shops, be it in the countryside or the suburb, but no landowner restricted their spending to the immediate vicinity of their estate. Whittle and Griffiths note the importance of Kings Lynn and Norwich to the spending patterns of the Le Strange family; Bailey notes the Gibbard's reliance on Bedford suppliers, and Stobart demonstrates how the Leighs drew on retailers in Warwick and Coventry to service Stoneleigh Abbey. ${ }^{65}$ London was also important to all these families and, indeed, to all wealthy consumers, not least because many spent at least a portion of the year in the metropolis. Mary Leigh had lived in London during her youth and so her links to metropolitan retailers were understandably strong. During the 1750s and 1760s, she had shopped in the streets of London's expanding West End and around Covent Garden and Long Acre, but also further east in the City. Most notable amongst the last of these were Carr, Ibbetson, Bigge, Packard \& Gibson, at the Queen's Head in Ludgate Hill who billed Mary on ten occasions, to a total value of $€ 195$ 7s, and supplied her with the highest quality dress materials. ${ }^{66}$ 
After Mary took up residence in Grove House, the geography of her London shopping changed somewhat: Covent Garden appears to have been largely abandoned, perhaps in response to the declining reputation of the area, and West-End retailers were patronised less often. There were some important retailers there, not least Thomas Ballard of South Audley Street, who billed Mary on twenty-three occasions between 1789 and 1800 during which time he was probably her main supplier of tea, coffee and chocolate. ${ }^{67}$ And yet, despite the general drift westwards of fashionable shops, noted by Adburgham, ${ }^{68}$ Mary became more reliant on traditional retail areas in and around the City where some of her key suppliers were located. Culinary groceries came from Frances Field of Holborn, and North, Hoare \& Hanson on New Bridge Street, just west of St Paul's, who together billed Mary on twenty-seven occasions and for a total of $€ 73611 \mathrm{~s} 8 \mathrm{~d} ;$;9 $^{\circ}$ silverware was supplied by Robert and Thomas Makepeace, who billed Mary for $£ 1518$ 11s 11d of engraved tableware including waiters, tureens, beef dishes, toast trays, tea vases, coffee pots and candle sticks; ${ }^{70}$ Wedgwood, as we have already noted, supplied large quantities of Greek Border and Queensware, and Edward Fell (her brother's old tailor) was the chief source of livery in the 1790 s, billing Mary for over $£ 1110$ of clothing for her servants. ${ }^{71}$ This huge outlay underlines the importance that she accorded to the appearance of her servants; so too does the fact that she went to her brother's old tailor for this clothing rather than rely on local suppliers as she did for her Warwickshire servants.

Given their proximity, this engagement with London shops is unsurprising, but it covered a much wider geographical area than was the case for other wealthy women. Judith Baker, for example, made annual trips to London in the third quarter of the eighteenth century, lodging with relatives near Grosvenor Square. ${ }^{72}$ She shopped nearby, in New Bond Street, Hanover Square and Berkeley Square; slightly further afield in Jermyn Street and Coventry Street, and about two miles distant on the Strand and Holborn. In these places, she bought from a relatively small number of retailers, basing her choice on a 'system of patronage, personal acquaintance and credit', ${ }^{73}$ but her restricted spatial horizon might also reflect her reluctance to hire a coach that would have allowed more distant journeys. As we have already noted, Mary Leigh 
frequently travelled by coach and thus had access to a wider set of shopping streets. At the same time, it is clear that much of this shopping was done remotely: the day book notes payments for servants to travel into London and for the carriage of hampers of groceries, some from Wilson \& Co. of St Paul's Churchyard.

Grove House and with it the suburb of Kensington were thus closely tied to metropolitan systems of supply; they were part of a complex web of traffic that articulated London's economy. But networks of supply were broader and more complex than this. Mary Leigh, like many of her peers, spent part of the year in one of the fashionable spa resorts and drew supplies from these places as well. Whilst Bath remained popular at this time, Mary preferred Cheltenham - increasingly in favour amongst the elite following patronage by George III. She went there in the autumn before travelling onto Kensington and placed orders with Cheltenham retailers which were then forwarded to her. The day book contains payments for the carriage of boxes and hampers from the spa, whilst Miss Baker wrote to her in 1796 that 'Mr Townsend ... promises he will imediately [sic.] on receiving the pattern shoe make six pair to your order for which with silk heels he must charge twelve shillings per pair'. ${ }^{74}$ Such arrangements were quite common amongst the provincial gentry, but are more striking when they involved someone living in the metropolis. They effectively reversed the flow of goods created by London retailers setting up shop for the season in Bath, Cheltenham and other resorts.

Only a modest quantity of goods were bought and sold in this way. Far more important in supplying Grove House was a steady stream of food being sent up from the country and recorded in an 'Account of Sundry's Receivd from Stoneleigh Abbey'. ${ }^{75}$ Taking 1794 as an example, there were 45 consignments spread over eleven months, none being sent in August and just one apiece in September and October - the months when Mary Leigh was at Stoneleigh or Cheltenham. In total, 31 different types of food were sent, including fruit and vegetables, domestic livestock and game (see Table 1). Cucumbers were by far the most common item sent, with other hothouse or tender fruits featuring regularly. Alongside these came substantial quantities of poultry, supplementing the supplies bought locally from Henry Davis, and a 
smaller amount of pork and lamb. Most important, at least symbolically, were consignments of game, mostly rabbits and wildfowl, but also a total of fourteen whole deer. Whilst the fruit, vegetables and animals produced in the gardens at Stoneleigh Abbey were important in provisioning Mary's dinner table in Kensington, game and particularly venison spoke of her status as a landowner. In addition to the strictures of the game laws, only the very wealthy could afford to dedicate large amounts of land to rearing deer, whether for sport or ornamentation. ${ }^{76}$ The London suburb was thus linked to the countryside as well as to the city in both practical and symbolic terms. Moreover, the flow of goods and meanings spread out from Grove House as Mary made gifts of melons, French beans, pines, cucumbers and venison to her friends, especially Joseph Hill. ${ }^{77}$ In this way, this suburban villa acted as a conduit, channelling goods, money, patronage and cultural capital into and out from London.

Table 1. Sundries sent from Stoneleigh Abbey to Grove House, Kensington, 1794

\begin{tabular}{lrlrlr}
\hline Fruit \& Veg. & N & Domestic livestock & n & Game & $\mathrm{n}$ \\
\hline cucumber & 582 & fowl & 37 & rabbit & 29 \\
peach & 66 & duck & 22 & woodcock & 23 \\
melon & 45 & turkey & 17 & partridge & 18 \\
lettuce & 29 & quarter pig & 15 & hare & 14 \\
french beans & 22 & guinea fowl & 9 & doe / buck & 14 \\
flower box & 17 & ham & 8 & pheasant & 8 \\
cheese & 15 & bacon & 4 & wild duck & 6 \\
pine & 12 & quarter lamb & 3 & snipe & 4 \\
mushrooms & 11 & loin of pork & 3 & haunch of venison & 2 \\
potatoes & 8 & black pudding & 3 & & \\
peas & 5 & sausages & 2 & & \\
\hline
\end{tabular}

Source: SCLA, DR18/31/655 Sundries from Stoneleigh Abbey

\section{Conclusion}

What, then, was the position of the suburban villa? Was it a retreat from the city or a convenient place for commuting into London? Gerhold concludes that 'villas were largely about pleasure 
and escape from obligations', but is it clear that the position was not this straightforward: the division of time between town and suburb was a complex mix of seasonal, weekly and daily movements which tied the villa to the complexities of metropolitan life. ${ }^{78}$ Both these divisions and connections, and the purpose and use of the villa itself, were further complicated if the owners also had a country estate. Grove House was indeed a retreat from the city - Mary Leigh moved there having previously lived in the West End - but it was also a base from which to engage in London's social life, albeit it a fairly modest way. The house was closely linked to the city both through flows of goods and people, and in the mental landscape of its owner. However, it was distinctly rural in its milieu: surrounded by fields and livestock in which Mary showed more than a simply fashionable interest. These attractions were reflected elsewhere: Dover House, an impressive mansion in Roehampton, was lauded by George Richardson in his New Vitruvius Britannica of 1802 as a place where the quiet of rural amusements may be mingled with the charms of polished society'. ${ }^{79}$ As with the classic villas of ancient Rome or Renaissance Italy, this rural setting was a central element of the attraction of suburban villas. It was this that made Grove House 'so agreeable and suitable a place' in which to live. Yet its position in relation to the city was complicated by its relationship with the country house which formed a more complete form of escape and a place to which guests could be invited rather than one in which visitors were received. Places like Grove House thus occupied a liminal position, intermediate between town and country. For wealthy landowners like Mary Leigh, they formed an alternative to the hothouse of London's St James' and Grosvenor Squares; not simply an escape from the city, but a different mode of living, as much rural as urban. This forms a challenge to the usual view of villas as a retreat for urban dwellers; it could also form a bridge into the city for those whose other affiliations were with the country.

The longer term fortunes of Grove House and neighbouring Gore House are also useful in marking the development of the suburban villa. Through the second half of the eighteenth and first half of the nineteenth centuries, they were occupied by members of the social and political elite. Kensington remained distinct from the city both geographically and culturally. By the 
1850s, London was fast encroaching on the fields and closes of the Gore estate, a process accelerated by the Great Exhibition the Commissioners of which bought the estate and later demolished both houses and others on the estate to construct the Albert Hall. Kensington was thus made central to the new imperial symbolism of Victorian London. ${ }^{80}$ Those seeking a retreat from the city, meanwhile, were looking much further afield. Improved transport and changing aspirations had made the country house a more attractive option. They were increasingly accessible for the weekend and offered better opportunities for shooting parties or riding to hounds, pastimes which conferred status and facilitated sociability. In some respects, then, the country house took on the mantle of the suburban villa as the destination for elites escaping the city. At the same time, the meaning and character of the 'suburban villa' was transformed. No longer a substantial house for elite families, it became the home and symbol of the burgeoning middle classes who commuted daily to their places of work. It was a still a retreat, but now firmly part of the city which was itself increasingly a middle-class space. 


\section{Notes}

${ }^{1}$ Shakespeare Central Library and Archive (SCLA), DR18/671 - letter to Joseph Hill, 27 March 1791.

${ }^{2}$ Ian Gow, uses the term 'villadom' in relation to developments around London and Edinburgh - see, Ian

Gow 'The Edinburgh villa revisited: function not form', in The Georgian Villa ed. Dana Arnold, (Stroud: Alan Sutton, 1996), 144.

${ }^{3}$ Alistair Rowan, 'Villa variants', in The Georgian Villa ed. Dana Arnold, (Stroud: Alan Sutton, 1996), 93. See also Mark Girouard, Town and Country (New Haven: Yale University Press, 1992), 235-8; Dorian Gerhold, Villas and Mansions of Roehampton and Putney Heath (Wandsworth: Wandsworth Historical Society, 1997); Caroline Knight, London's Country Houses (Chichester: Phillimore, 2009).

${ }^{4}$ Deborah Howard, 'The Italian Renaissance villa: the reconciliation of nature and artifice', in The Georgian Villa ed. Dana Arnold, (Stroud: Alan Sutton, 1996), 1-10. See also David Coffin, The Villa Life of Renaissance Rome (Princeton, NJ: Princeton University Press, 1979).

${ }^{5}$ On Dutch developments, see Yme Kuiper 'The rise of the country house in the Dutch Republic. Beyond Johan Huizinga's narrative of Dutch civilisation in the seventeenth century' in The Country House: Material Culture and Consumption, ed. Jon Stobart and Andrew Hann (London: English Heritage, forthcoming 2015).

${ }^{6}$ Dorian Gerhold, 'London's suburban villas and mansions, 1660-1830', The London Journal, 34:3 (2009), $250-52$.

${ }^{7}$ Julius Bryant, 'Villa views and the uninvited audience', in The Georgian Villa ed. Dana Arnold, (Stroud: Alan Sutton, 1996), 14-20.

${ }^{8}$ Quoted in Gerhold, 'London's suburban villas', 234.

${ }^{9}$ Daniel Defoe, Journey Through ... Great Britain (1724; Harmondsworth: Penguin, 1978), 121.

10 Gerhold, 'London's suburban villas', 235-44.

${ }^{11}$ See William Albert, The Turnpike System in England, 1663-1840 (Cambridge: Cambridge University Press, 1972), 202-3; Dorian Gerhold, Carriers and Coachmasters. Travel and Trade before the Turnpikes (Chichester: Phillimore, 2008), 152.

12 Porter, London, 120-22.

${ }^{13}$ Gerhold, 'London's suburban villas', 251.

${ }^{14}$ See, for example, SCLA, DR18/5/4620 - bill from Thomas and Gilbert Burnett. 
${ }^{15}$ Mark Rothery and Jon Stobart, 'Inheritance events and spending patterns in the English country house: the Leigh family of Stoneleigh Abbey, 1738-1806' Continuity and Change, 27:3 (2012), 379-407. By the early nineteenth century, the estate's value had risen to c.£19,000 per annum; SCLA DR18/31/16-37, Rentals of Real and Devised Estates 1762-1806.

${ }^{16}$ SCLA, DR18/23/14 - Lease on Grove House, 1788.

${ }^{17}$ P. Mathias, 'The social structure in the eighteenth century: a calculation by Joseph Massie', in idem., The transformation of England: essays in the economic and social history of England in the Eighteenth century. (London 1979), 171-89.

${ }^{18}$ Gerhold, 'London's suburban villas', 255.

${ }^{19}$ Paget Toynbee (ed.), The Letters of Horace Walpole, vol. vi (Oxford: Clarendon Press, 1904), 318

${ }^{20}$ Quoted in Survey of London, Volume 38: South Kensington Museums Area (1975), 12.

${ }^{21}$ Humphrey Repton, Fragments on the Theory and Practice of Landscape Gardening (London, 1816). Amanda Vickery, Behind Closed Doors. At Home in Georgian England (New Haven: Yale University Press, 2009), 83-8.

${ }^{22}$ Jon Stobart and Mark Rothery, 'Fashion, heritance and family: new and old in the Georgian country house', Cultural and Social History 11:3 (2014), 385-406.

${ }^{23}$ SCLA, DR18/5/5703 - bill from Michael Thackthwaite, upholsterer. Thackthwaite was at Stoneleigh Abbey in July and August of 1786, drawing up an inventory following the death of the fifth Lord Leigh. This suggests that his bill for furniture and upholstery referred to goods supplied for Stoneleigh. However, it is impossible to identify in the 1806 inventory for Stoneleigh Abbey any of the pieces supplied, even though some are quite distinctive. The items and room names appear to fit the Kensington rather than Warwickshire house.

${ }^{24}$ SCLA, DR18/5/5980 - bill from Bradhsaw and Smith, upholsterers.

${ }^{25}$ For discussion on the idea of comfort, see John Cornforth, Early Georgian Interiors (New Haven: Yale University Press, 2004); John Crowley, The Invention of Comfort. Sensibilities and Design in Early-Modern Britain and Early America (Baltimore: John Hopkins University Press, 2000). On neatness and gentility, see Amanda Vickery, The Gentleman's Daughter. Women's Lives in Georgian England (New Haven: Yale University Press, 1998), 13-38.

${ }^{26}$ SCLA, DR18/5/5980- bill from Bradhsaw and Smith, upholsterers. 
${ }^{27}$ SCLA, DR18/5/5703 - bill from Michael Thackthwaite, upholsterer.

${ }^{28}$ Woodruff Smith, Consumption and the Making of Respectability, 1600-1800 (London: Routledge, 2002), 115-16, 130-38; Beverly Lemire, 'An education in comfort: Indian textiles and the remaking of English homes over the long eighteenth century', in Selling Textiles in the Long Eighteenth Century. Comparative Perspectives from Western Europe, ed. Jon Stobart and Bruno Blondé (London: Palgrave, forthcoming, 2014).

${ }^{29}$ See SCLA, DR18/17/31/4 - Letter about renewal of lease, 1800. In her draft response (written on the back of this letter), Mary lays out the conditions of her lease and states that 'Mr Magnolly stands to the repairs', suggesting that she may have been reimbursed for this expenditure. However, there is no indication in the Stoneleigh accounts to confirm this.

${ }^{30}$ SCLA, DR18/5/6125 - bill from Thomas Watts, glazier; DR18/5/6126 - bill from John Weston, plasterer; DR18/5/6130 - bill from Joseph Naylor, painter; DR18/5/6129 - bill from James Fisher, carpenter.

${ }^{31}$ See note 14, plus SCLA18/5/6122 - bill from Barnet \& Mason, masons; DR18/5/6123 - bill from M. Storer, plumber; DR18/5/6124 - bill from Thomas Poole, bricklayer.

32 Quoted in Gerhold, 'London's suburban villas', 258.

${ }^{33}$ J.D. Williams, 'The noble household as a unit of consumption: the Audley End experience, 1765-1797', Essex Archaeology and History, 23 (1992), 67-78.

${ }^{34}$ Peter Hammond and Carolyn Hammond, Life in an Eighteenth-Century County House (Stroud: Amberley Publishing, 2012), 69. Whilst the authors describe this as a country house, it was effectively a suburban villa.

${ }^{35}$ Porter, London, 122. The frequency of balls might have been in Walpole's mind when he likened Grove House to a guinguette - that is, a rural drinking resort.

${ }^{36}$ Gerhold, 'London's suburban villas', 234.

${ }^{37}$ SCLA, DR 18/5/5684 - bill from Josiah Wedgwood.

${ }^{38}$ SCLA, DR18/4/46 list of china at Grove House; DR18/4/47 - plate sent down by Mr Hill from Grove House.

${ }^{39}$ Lady Sefton and Mrs St John were the sisters of William Craven, Mary's cousin and owner of Coombe Abbey, a neighbouring estate in Warwickshire. 
${ }^{40}$ See, for example, SCLA, DR671 - letter to Joseph Hill, 28 January 1792.

${ }^{41}$ Quoted in Gerhold, 'London's suburban villas', 256.

${ }^{42}$ SCLA, DR18/17/29/30 - letter from Arthur Gregory, 21 June 1789.

${ }^{43}$ SCLA, DR671, letter to Joseph Hill, 12 September 1791

${ }^{44}$ This pattern of movement does no conform to any of those noted by Gerhold, 'London's suburban villas', 254.

${ }^{45}$ Quoted in Gerhold, 'London's suburban villas', 256.

${ }^{46}$ SCLA, DR18/671/52 - letter from Mary Elizabeth Parker, 25 March 1791.

${ }^{47}$ SCLA, DR18/31-656 - Day Brook for Grove House, 1793-98.

${ }^{48}$ SCLA, DR18/671 - letter to Joseph Hill, 2 December 1791

${ }^{49}$ Greig, Beau Monde, 32-62 Vickery, Behind Closed Doors, 274-6, 294-5; Gerhold, 'London's suburban villas', 256.

${ }^{50}$ SCLA, DR18/5/6098 - bill from Edward Fell. They were also supplied with trimmed hats. The bill from Fell included 9s 6d for 'ripping to pieces a claret colour frock suit and greatly altered for a new postilion \& made to his size'.

${ }^{51}$ John Styles, The Dress of the People. Everyday Fashion in Eighteenth-Century England (New Haven: Yale University Press, 2007), 295-301.

${ }^{52}$ SCLA, DR671 - letter to Joseph Hill, 30 July 1791.

${ }^{53}$ SCLA, DR18/23/14 - list of books at Grove House, 1806.

${ }^{54}$ See Mark Purcell, “'A lunatick of unsound mind": Edward, Lord Leigh (1742-86)', Bodleian Library Record, 17 (2001), 246-60.

55 Gerhold, 'London's suburban villas', 245.

${ }^{56}$ SCLA, DR18/23/14 Particulars and Conditions of Sale of Gore House, 1790. The lease on Gore House was purchased for $£ 2500$ from the executors of 'Governor Johnstone'; see SCLA, DR18/17/30/1 - Letter from Joseph Hill, 1790; DR18/5/5903 - receipted bill from Joseph Hill, 1 January 1791.

${ }^{57}$ SCLA, DR18/31-656 - Day Brook for Grove House, 1793-98.

${ }^{58}$ SCLA, DR18/671 - letters to Joseph Hill, 11 February 1791, 11 June 1791.

${ }^{59}$ SCLA, 18/17/30/41 - letter from Joseph Hill, 19 June 1796; DR18/17/31/3 - letter from Isola Magnally, 24 February 1800. 
${ }^{60}$ Hammond and Hammond, Country House, 32, 52.

${ }^{61}$ Gow, 'The Edinburgh villa', 146-7.

${ }^{62}$ SCLA, DR18/17/32/70 - list of servants discharged, 1806; DR18/671 - letter to Joseph Hill, 11 February 1791.

${ }^{63}$ SCLA, DR18/31-656 - Day Brook for Grove House, 1793-98.

${ }^{64}$ At Morice's Chiswick house, there was a similarly regular stream of meat, coal and oats from local suppliers - Hammond and Hammond, Country House, 27, 32, 37.

${ }^{65}$ Jane Whittle and Elizabeth Griffiths, Consumption and Gender in the Seventeenth-Century Household. The World of Alice le Strange (Oxford: Oxford University Press, 2013), 55-64; Lucy Bailey, 'Consumption and status: shopping for clothes in a nineteenth-century Bedfordshire gentry household', Midland History, 2010; Jon Stobart, "Gentlemen and shopkeepers: supplying the country house in eighteenth-century England', Economic History Review 64:3 (2011), 885-904.

${ }^{66}$ SCLA, DR18/5/4303, DR18/5/4441. Importantly, these textiles were bought in 21 and 23 yard lengths; those from Croft and Hinchcliff were in 12 and 16 yard lengths, suggesting more complex and elaborate dresses. See Anne Buck, Dress in Eighteenth-Century England (London: Harper Collins , 1979).

${ }^{67}$ See, for example, SCLA, DR18/5/5851 - bill from Thomas Ballard, DR18/5/5998 - bill from Thomas Ballard.

${ }^{68}$ Alison Adburghan, Shops and Shopping, 1800-1914 (London: Allen and Unwin, 1981), 12-18.

${ }^{69}$ See, for example, the large consolidated bills from Francis Field: SCLA, DR18/5/5865. For fuller discussion of the kind of groceries supplied by Field, see Jon Stobart, Sugar and Spice. Grocers and Groceries in Provincial England, 1650-1830 (Oxford: Oxford University Press, 2013), 50-55.

${ }^{70}$ SCLA, DR18/5/5809.

${ }^{71}$ For example, SCLA, DR18/5/6039a - bill from Messrs Fell; DR18/5/6043 - bill from Messrs Fell.

${ }^{72}$ Helen Berry, 'Prudent luxury: the Metropolitan tastes of Judith Baker, Durham gentlewoman', in Out of Town: Women and Urban Life in Eighteenth-Century Britain, ed. Penny Lane and Roey Sweet (Aldershot: Ashgate, 2005), 143-52.

${ }^{73}$ Berry, 'Prudent luxury', 146.

${ }^{74}$ SCLA, DR18/17/30/35 - letter from Miss Baker, 19 April 1796. A draft response on the same letter details the arrangements for payment and delivery via the mail coach. 
${ }^{75}$ SCLA, DR18/31/655 Account of Sundries from Stoneleigh Abbey, 1793-98.

${ }^{76}$ Sara Paston-Williams, The Art of Dining. A History of Cooking and Eating (Oxford, 1993), 207; Whittle and Griffiths, Consumption and Gender, 116.

${ }^{77}$ See, for example, SCLA, DR18/671 - letters to Joseph Hill, 11 June 1791, 28 January 1792, 25 February 1792.

${ }^{78}$ Gerhold, 'London's suburban villas', 259.

${ }^{79}$ Quoted in Gerhold, 'London's suburban villas', 248.

${ }^{80}$ See Tristram Hunt, Building Jerusalem: The Rise and Fall of the Victorian City (London: Weidenfeld \& Nicholson, 2004), 285-307, who also discusses the suburbanisation of the middle classes. 